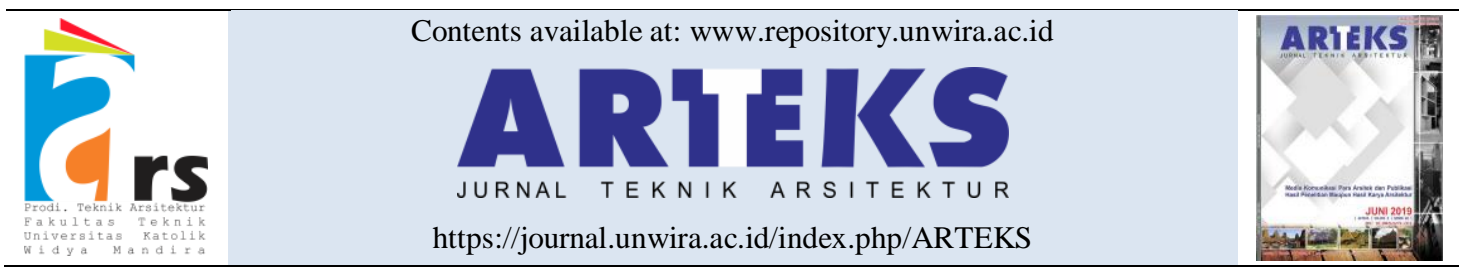

Research paper

doi: 10.30822/arteks.v5i2.389

\title{
Penerapan prinsip desain Daniel Libeskind pada fasilitas permainan tradisional Melayu Riau di Pekanbaru
}

\author{
Elza Fitria Ningsih, Yohannes Firzal ${ }^{\circledR}$, Pedia Aldy* \\ Jurusan Arsitektur, Fakultas Teknik, Universitas Riau \\ Kampus Binawidya, Jl. HR. Soebrantas KM. 12,5 Pekanbaru, Indonesia
}

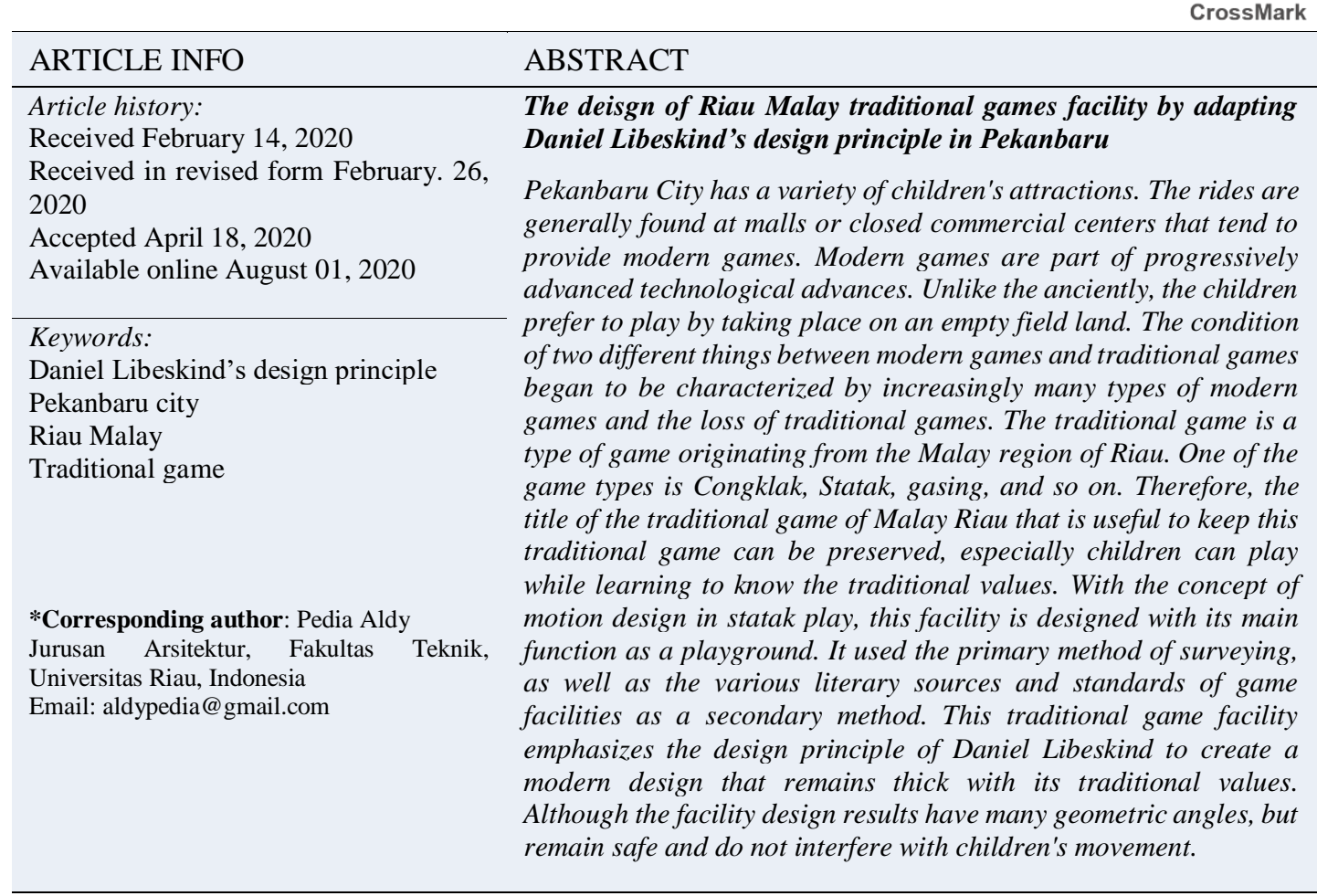

\section{Pendahuluan}

Kota Pekanbaru merupakan Ibukota Provinsi Riau. Berdasarkan Peraturan Daerah Provinsi Riau Nomor 9 Tahun 2015 tentang Pelestarian Kebudayaan Melayu Riau, bahwa kebudayaan Melayu Riau merupakan bagian dari kebudayaan nasional yang harus dilestarikan melalui pengelolaan yang menjamin kemajuan peradaban dan mempertinggi derajat kemanusiaan serta mempertahankan identitas daerah di tengahtengah arus globalisasi ini (Pemerintah Provinsi Riau 2015). Dalam era globalisasi, perkembangan Ilmu dan Teknologi (IPTEK) dapat menimbulkan perubahan tingkah laku manusia khususnya pada anak-anak (Nurhaidah 2015). Menurut Dahliani (2015), globalisasi memengaruhi kearifan lokal melalui pola pikir manusia (Dahliani 2015). Negara berkembang seperti Indonesia akan nyaris kehilangan segala sesuatu yang bersifat tardisional, misalnya pada permainan tradisional. Menurut Rini (2011), maraknya game online, seakan menuntut anak-anak mengikuti trend masa sekarang (Rini 2011). Berdasarkan penelitian yang dilakukan Angela (2013), motivasi belajar pada anak yang menyukai game online cenderung rendah, karena anak lebih memilih kegiatan yang mengasyikan, malas belajar bahkan tidak peduli 
dengan tugas-tugas sekolahnya (Angela 2013). Game online telah menjadi teman waktu anak saat mereka bosan. Kondisi seperti ini disebabkan permainannya yang hanya akan mengkonsumsi kuota, dengan kemudah akses dan tanpa harus keluar rumah (Christina and Suprobo 2017).

Dengan pola perilaku seperti di atas, banyak anak dan remaja zaman sekarang lebih mengenal permainan modern dibandingkan permainan tradisional, khususnya remaja yang tinggal di daerah perkotaan karena minimnya lahan kosong untuk tempat bermain. Kemudian, dengan kesibukan orang tua dalam bekerja mengakibatkan tidak adanya pengenalan dan pengetahuan tentang permainan tradisional (Santoso 2015).

Dari fenomena tersebut, untuk konteks perkotaan khususnya di Kota Pekanbaru dengan berdasarkan Peraturan daerah Provinsi Riau, bahwa pada pasal 45 yang salah satu isinya dapat meningkatkan kreativitas dan inovasi dari permainan tradisional. Salah satu dampak positif bagi anak-anak ialah dapat menciptakan karyakarya baru dalam meningkatkan kemajuan permainan tradisional, menjalin solidaritas antar sesama, meningkatkan jiwa sosial serta menambah keakraban dengan teman sebaya. Oleh karena itu, diperlukan sebuah wadah untuk memperoleh dampak positif tersebut dengan melalui fasilitas permainan tradisional Melayu Riau dengan menerapkan prinsip desain Daniel Libeskind di Pekanbaru. Prinsip desain Daniel Libeskind ini merupakan suatu prinsip dalam dunia arsitektur oleh arsitek Daniel yang cenderung menciptakan bentukan-bentukan baru dan berbeda dari arsitek lainnya. Perbedaan inilah yang membuat karya-karyanya dikenal banyak orang, cirinya ditandai dengan bangunan yang cenderung bersudut-sudut tajam tanpa mengganggu pergerakan orang di dalam bangunan. Keterkaitan antara prinsip dengan fungsi fasilitas permainan tradisional anak terdapat pada pola pikir anak yang harus bisa menciptakan sesuatu yang baru mengikuti perkembangan zaman, tetapi tidak megurangi keaslian sebelumnya, misalnya pada permainan tradisional ini yang tetap mempertahankan nilai tradisionalnya, contohnya dalam cara memainkan suatu permainan yang sudah ada sejak zaman nenek moyang.

Pada perancangan fasilitas permainan tradisional Melayu Riau terdapat satu gedung utama sebagai arena bermain di dalam ruangan (indoor), dilengkapi dengan arena bermain diluar ruangan (outdoor) serta dilengkapi juga dengan fasilitas pendukung lainnya yang dapat menambah daya tarik wisata anak-anak. Adapun manfaat dari perancangan ini yaitu dapat memperkenalkan kepada anak-anak mengenal apa-apa saja jenis permainan tradisional, khususnya permainan tradisional di daerah Melayu Riau yang sudah sangat jarang dimainkan yang kemudian diperkenalkan lagi ke anak-anak zaman sekarang dengan cara yang lebih modern.

\section{Metode penelitian}

Dalam perancangan fasilitas permainan tradisional Melayu Riau ini, memerlukan pendekatan berbeda, namun tetap mencerminkan identitas wahana permainan tradisional anak. Fasilitas untuk kriteria usia anak-anak bermain pada wahana permainan tradisional ini berkisar antara 6-18 tahun. Golongan usia tersebut, anakanak sudah dapat membedakan permainan yang satu dengan yang lainnya (Rohmah 2016; Hasanah 2016), serta dapat berrmanfaat pada sisi edukasi terkait jenis-jenis permainan tradisional anak yang berasal dari Riau yang dirancang berdasarkan prinsip dari Daniel Libeskind. Strategi perancangannya dibuat beberapa tahapan seperti menganalisa fungsi, menganalisa site, membuat program ruang, penzoningan, pola hubungan dan penataan ruang, konsep perancangan, bentukan massa, struktur, utilitas, fasad, tatana ruang luar, dan lansekap diharapakan dapat menghasilkan desain modern yang tetap kental dengan nilai tradisional.

Metode pengumpulan data

Data dikelompokkan menjadi 2 bagian; data primer yang dikumpulkan melalui pengamatan langsung terhadap objek berupa survei lapangan dan dokumentasi yaitu berdasarkan hasil survei yang pertama (Sudradjat 2020), bahwa sudah jarang bahkan tidak ada anak-anak yang bermain di luar rumah, anak-anak sudah terbiasa bermain menggunakan handphone pribadi miliknya dan bahkan ada juga yang bermain ke warnet-warnet sampai lupa untuk pulang ke rumahnya, sehingga sering kali anak-anak lupa mengerjakan pekerjaan rumah (PR) yang diberikan oleh gurunya di sekolah. Hasil survei yang kedua, karena tidak adanya lahan kosong serta fasilitas bermain di mall-mall besar lebih efisien, anak-anak lebih tertarik pada permainan yang mengeluarkan biaya 
saat bermain, misalnya bom-bom car, trampoline, ice skating, dan lain sebagainya. Beda halnya dengan permainan tradisional yang tidak menggunakan biaya, tetapi mengharuskan anakanak untuk belajar mandiri. Untuk data sekunder yang merupakan kompilasi dari berbagai sumber literatur ilmiah seperti referensi permainan tradisional, literatur terkait prinsip desain arsitektur dekonstruksi Daniel Libeskind, dan studi referensi yang terkait dengan fungsi sejenis seperti tinjauan terhadap kampung wisata
Ledokombo (Saputra, Muksin, and Muspita 2018), taman dolan Batu, taman pintar Yogyakarta (Hidayah 2016), serta kampung dolanan Prancak Pandes dan kampung dolanan Sidowayah (Pertiwi and Aliyah 2017). Sedangkan, kompilasi data skunder dengan tema sejenis diperoleh dari kajian terhadap fasilitas Crystals at city center, Kurdistan museum, the run-run shaw creative media center, dan centre de congress a mons. Berikut ini, bagan alur proses perancangan (Lihat gambar 1).

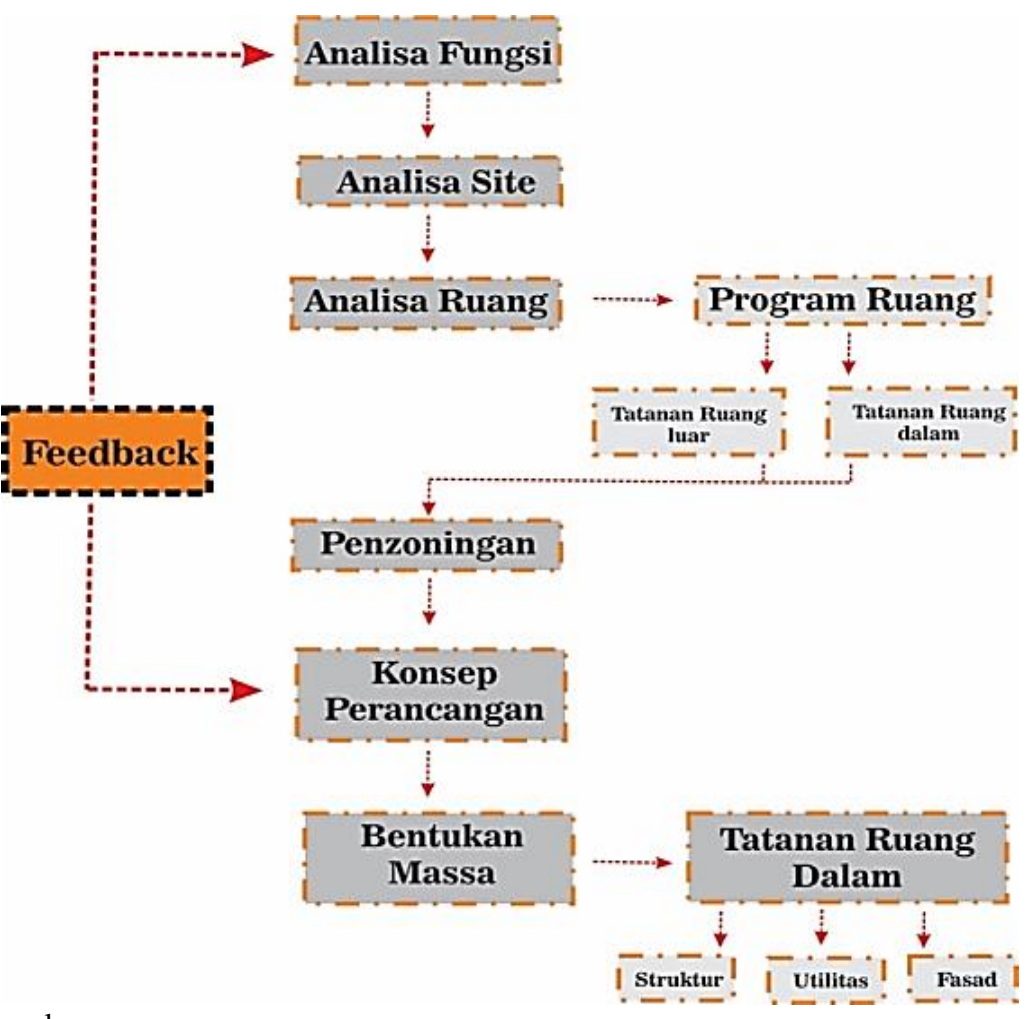

Gambar 1. Bagan alur perancangan

\section{Temuan dan pembahasan}

Menurut Andriani (2012), permainan tradisional merupakan simbolisasi dari pengetahuan yang turun temurun dan mempunyai bermacam-macam fungsi atau pesan dibaliknya (Andriani 2012). Manfaat permainan tradisional menurut Fatkhiyah (2015) dapat memengaruhi perkembangan anak berkaitan dengan tingkat kecerdasan intelektual anak, mengembangkan kecerdasan emosi anak, mengembangkan daya kreativitas pada anak, dan dapat meningkatkan kemampuan bersosialisasi, serta dapat melatih kemampuan motorik anak (Fatkhiyah 2015).
Untuk permainan-permainan tradisional, perancangan wadah ini memfokuskan pada permainan yang berasal dari Riau. Adapun jenisjenis permainannya yaitu berjumlah 13 jenis permainan tradisional yang dapat didistribuiskan pada arena indoor dan outdoor. Permainan di dalam ruangan (indoor) terdiri atas permainan congklak, gasing, statak, petak umpet, benteng dan biji karet. Sedangkan, jenis permainan yang berada di luar ruangan (outdoor) seperti lulu cina buta, bakiak, engrang, layang-layang, tarik tambang, kelereng dan ligu. 
Arsitektur dekonstruksi

Menurut Mantiri (2011), arsitektur dekonstruksi lahir dari pengaruh filusuf Derrida, sehingga disebut sebagai dekonstruksi Derridean (Mantiri and Makainas 2011). Selain itu, dalam konteks lebih khusus, arsitektur dekonstruksi hadir sebagai produk pragmatis dan formal dan dikenal dengan sebutan dekonstruksi nonderridean yang lebih mementingkan segi estetik (Lake 2017). Salah satu arsitek yang menjadi motor penggeraknya ialah Daniel Libeskind. Menurut Hermanto (2013), Daniel Libeskind lahir di Polandia, dikenal sebagai arsitek dengan pendekatan teoritis dan dikaitkan dengan paradigma Dekonstruksi. Karakter arsitektur dekonstruksi nonderridean dapat dikenali melalui garis-garis tidak beraturan, keseluruhan struktur seperti runtuh, dan bentukbentuk geometri yang cenderung berbentuk aneh (Hermanto 2013).

Pada perancangan fasilitas permainan tradisional Melayu Riau ini, prinsip desain Daniel Libeskind yang diterapkan berupa bentuk-bentuk geometri yang cenderung aneh dan dipengaruhi oleh adanya pembatasan penerimaan keabsolutan terhadap keaslian bentuk-bentuk geometri yang selama ini dikenal (Senasaputro, Bayu, and Nuryanti 2008).

Secara lebih detail, prinsip desain Daniel Libeskind dapat dijabarkan sebagai berikut: (a) metafora, menekankan pada ide yang diubah ke bentuk ruang tiga dimensional kemudian dituang ke dalam hasil akhir ekspresi karya arsitektur; (b) fragmentation, yang didefinisikan menjadi bagian, penggalan, kepingan, dan pecahan (Bitter 2011). Menurut Mantiri (2011) bahwa dalam merancang dengan berpegang pada kaidah-kaidah dekonstruksi, suatu objek akan mengalami dua proses utama yaitu diuraikan (deconstructing) ataupun dihancurkan (destroy) kedalam potongan-potongan (fragmentasi); (c) void, ditandai dengan suatu ruang kosong diantara lantai dan atap; (d) disorientation yang menurut Mantiri (2011), setelah mendapatkan proses fragmen, kemudian dirangkaikan kembali (reconstructing) menjadi bentuk baru dengan identitas yang sama sekali berbeda dengan sebelumnya (Mantiri and Makainas 2011).

\section{Lokasi perancangan}

Lokasi yang dipilih terdapat di Kota Pekanbaru. Alasannya, karena Pekanbaru merupakan Ibukota Provinsi Riau. Berdasarkan dari Peraturan Daerah Provinsi Riau yang sudah dijelakan sebelumnya, maka dipilihlah Kota Pekanbaru sebagai area perancangan fasilitas permainan tradisional, dimana selain belum terdapat area khusus untuk tempat bermain permainan tradisional juga dapat memperkenalkan kepada anak-anak zaman sekarang bahwa permainan tradisional tidak boleh dihilangkan akibat perkembangan permainan modern yang semakin pesat. Pada fasilitas permainan tradisional Melayu Riau ini direncanakan berada di Jalan Bima Kota Pekanbaru dengan luas lahan $\pm 25.000 \mathrm{~m} 2$, koefisien dasar bangunan (KDB) 70\%, dan kondisi kontur relatif datar (Lihat gambar 2).

Adapun alasan memilih lokasi yang berada di Jalan Bima tersebut adalah selain di sekitar tapak terdapat beberapa sekolah, lokasi tapak juga strategis, tidak jauh dari pusat kota, serta tidak jauh dari daerah Panam dengan jumlah penduduknya \pm 25.000 jiwa.

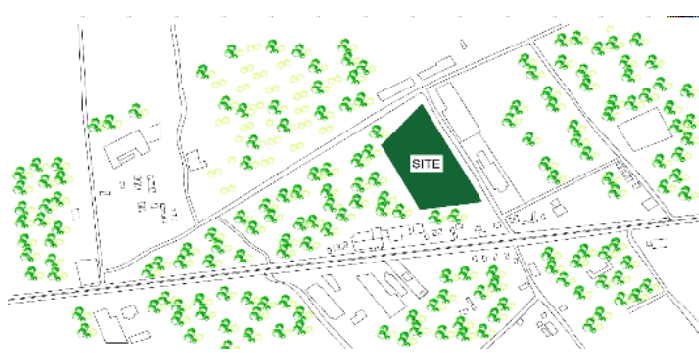

Gambar 2. Rencana lokasi fasilitas permainan tradisional Melayu Riau

Kondisi tapak berdekatan dengan jalan utama dan strategis. Lokasi dapat ditempuh dalam waktu \pm 16 menit dari pusat kota atau berjarak $\pm 7,3 \mathrm{~km}$, lokasi telah tersedia jaringan utilitas kota seperti jaringan listrik dan jalan beraspal (Lihat gambar $3)$.

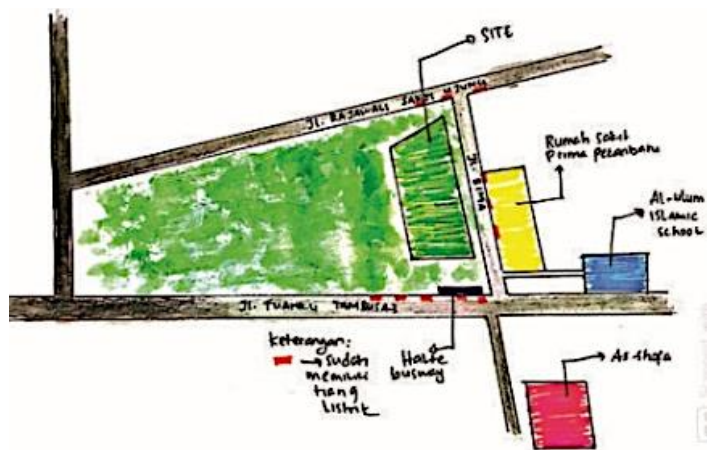

Gambar 3. Kondisi rencana tapak fasilitas permainan tradisional Melayu Riau 
Kebutuhan ruang

Berdasarkan ketersedian luas tapak dan perhitungan asumsi standar besaran ruangruangan fungsional (Neufert 2002), maka kebutuhan luas ruangan untuk fasilitas failitas permainan tradisional Melayu Riau dapat dikelompokkan besaran ruangan sebagai berikut (Lihat tabel 1):

Tabel 1. Kebutuhan ruang

\begin{tabular}{lll}
\hline No & Nama Ruang & $\mathbf{+ 3 0 \%}$ sirkulasi \\
\hline 1. & Ruang indoor & $1.670,00 \mathrm{~m}^{2}$ \\
\hline 2. & Ruang penunjang & $4.766,80 \mathrm{~m}^{2}$ \\
\hline 3. & Ruang pengelola & $5.57,50 \mathrm{~m}^{2}$ \\
\hline 4. & Ruang Servis & $484,92 \mathrm{~m}^{2}$ \\
\hline 5. & Ruang Outdoor & $5.566,50 \mathrm{~m}^{2}$ \\
\hline 6. & Ruang Luar & $6.450,00 \mathrm{~m}^{2}$ \\
\hline
\end{tabular}

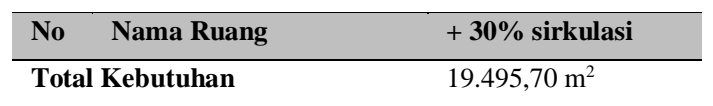

Dengan memperhatikan peraturan kota terkait koefisien daerah hijau bangunan, yang mensyaratkan 30\% dari luas tapak digunakan sebagai area taman/vegetasi di sekitar bangunan maka 5.875 dipersiapkan untuk kebutuhan daerah hijau, sehingga luas lahan keseluruhan yang dibutuhkan menjadi $25 \cdot 370,7 \mathrm{~m} 2$ atau $\pm 2,5$ ha.

\section{Penzoningan}

Penzoningan ruang fasilitas dilakukan untuk menempatkan atau mengelompokkan ruangan ke dalam area yang berkesesuaian fungsinya atau sifatnya seperti (Lihat gambar 4, gambar 5, dan gambar 6): (a) zona privat; (b) zona semi publik; (c) zona publik.

a. Zona privat

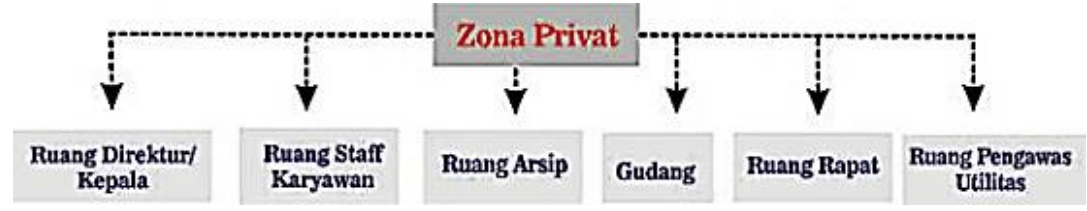

Gambar 4. Kebutuhan ruang pada zona privat

b. Zona semi publik

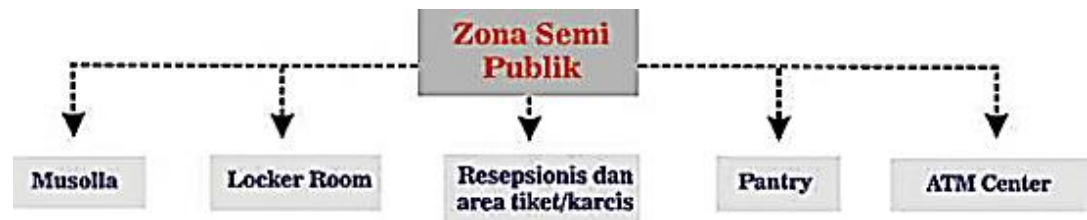

Gambar 5. Kebutuhan ruang pada zona semi publik

c. Zona publik

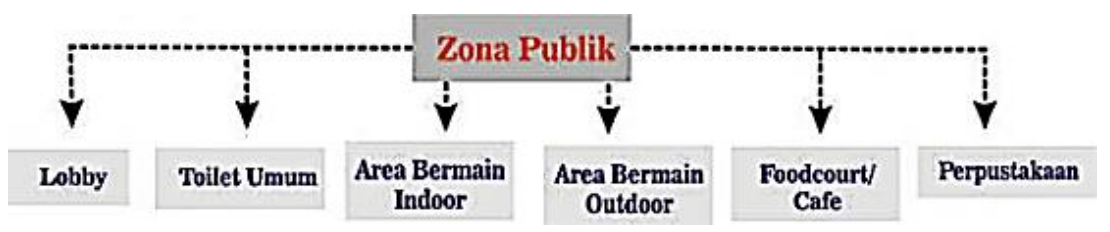

Gambar 6. Kebutuhan ruang pada zona publik

\section{Konsep}

Konsep dasar perancangan fasilitas permainan tradisional Melayu Riau ini adalah gerak dalam bermain statak. Alasan pemilihan konsep ini didasari atas inspirasi pada permainan statak, permainan tradisional, dengan mengadaptasi semua gerakan permainan seperti melompat, melempar, dan berjalan. Anak-anak dapat bergerak ekspresif saat bermain, dan dapat begerak sesuai keinginan (Lihat gambar 7). 


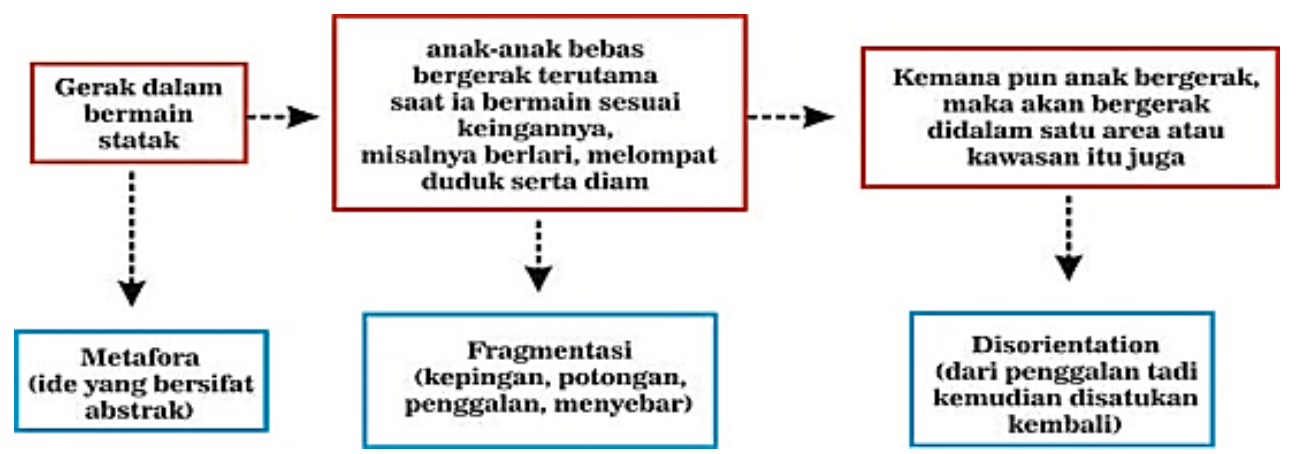

Gambar 7. Konsep dasar perancangan

Konsep bentuk massa

Konsep bentukkan massa bangunan juga berkaitan langsung dengan konsep dasar bangunan, dengan diperkaya penataan lansekap yang juga sesuai dengan konsep dasar perancangan (Lihat gambar 8).

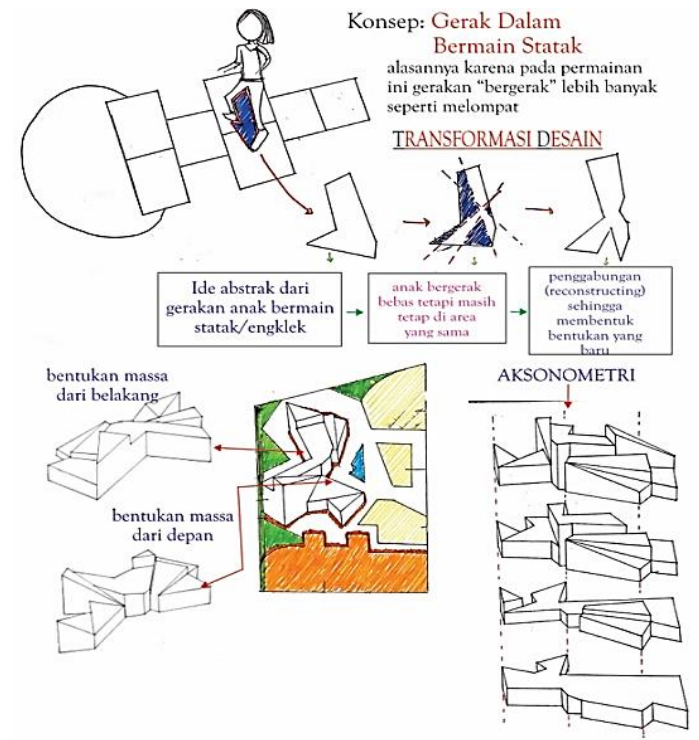

Gambar 7. Konsep bentukan massa

Konsep rencana tapak

Rencana tapak, dikelompokan atas area bermain outdoor, pada bangunan utama sebagai fasilitas area bermain indoor, serta area parkir (Lihat gambar 9).

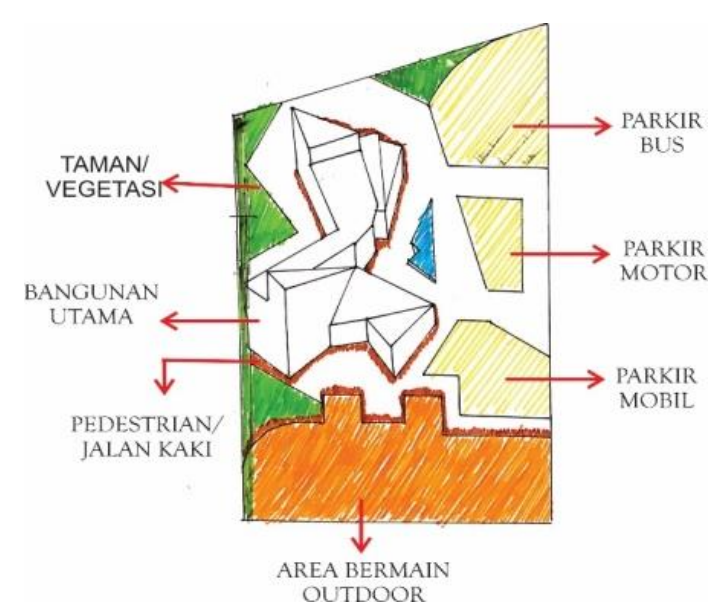

Gambar 9. Konsep rencana tapak

Konsep sirkulasi dan parkir

Rancangan pada pola sirkulasi dan parkir juga menyesuaikan dengan konsep dasar perancangan. Zona parkir antara kendaraan motor, kendaraan mobil, dan kendaraan bus dikelompokkan saling berdekatan. Sedangkan, jalur pedestrian untuk pejalan kaki dirancang terpisah sehingga, dapat menghindari persilangan antara kendaraan dan pejalan kaki (Lihat gambar 10).

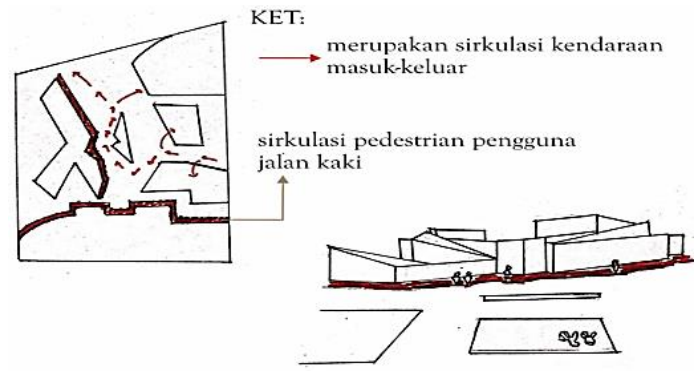

Gambar 8. Konsep sirkulasi dan parkir

Pencapaian

Racangan pola pencapaian keluar dan ke dalam tapak dengan sirkulasi masuk menuju tapak 
berada dari arah Barat atau berada di Jalan Bima. Sedangkan, untuk jalur keluar berada pada sisi Selatan tapak (Lihat gambar 11).

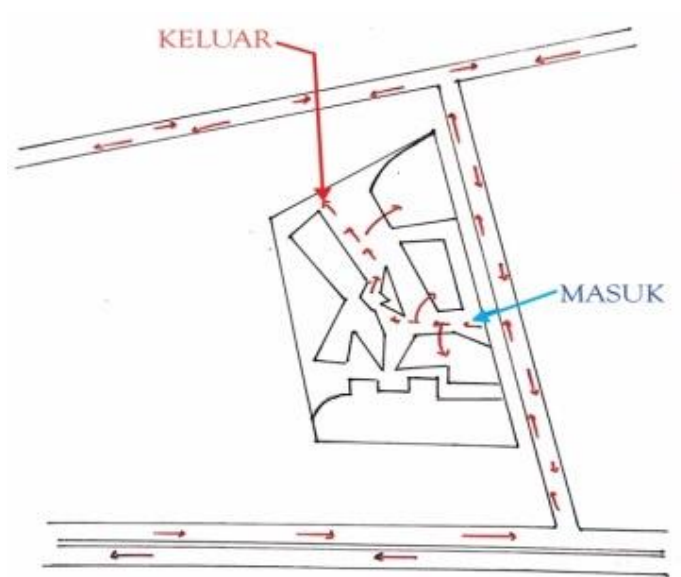

Gambar 9. Konsep pencapaian

\section{Penerapan tema}

Perancangan fasilitas permainan tradisional Melayu Riau ini menerapkan tema dekonstruksi oleh arsitek Daniel Libeskind dengan 4 metode prinsip perancangannya yaitu:

a. Metaphora, ide itu berawal dari pergerakan anak yang bergerak bermain statak dan menjadi pola dari bentuk bangunan (Lihat gambar 12).

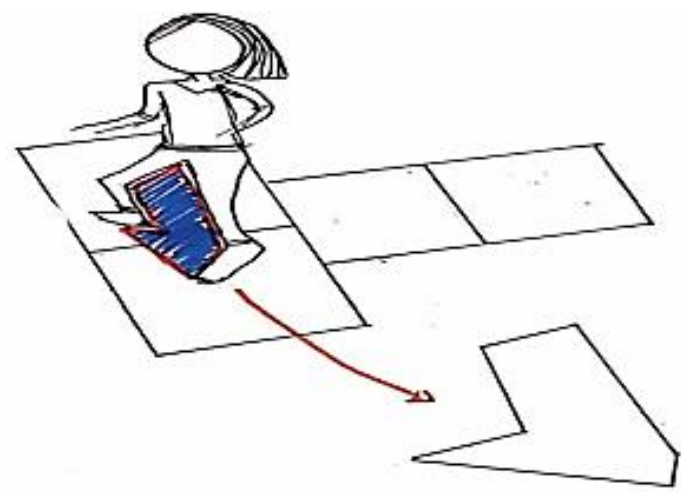

Gambar 10. Penerapan prinsip metaphora terhadap pergerakan permainan statak

b. Fragmentasi, dengan prinsip ini diterapkan pada fasad bangunan dengan membentuk garis tidak beraturan yang fungsinya untuk memasukkan cahaya dari luar ke dalam bangunan (Lihat gambar 13).

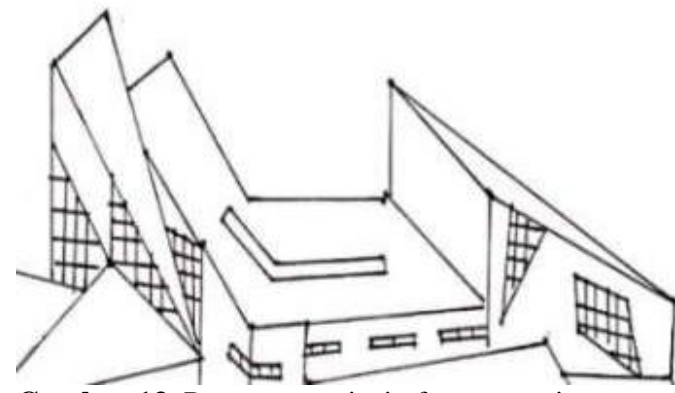

Gambar 13. Penerapan prinsip fragmentasi

c. Void, merupakan ruang kosong antara lantai dengan atap bangunan (Lihat gambar 14).

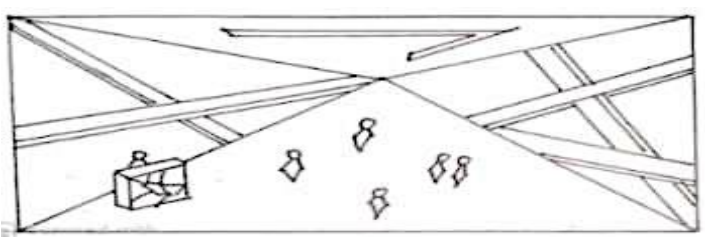

Gambar 11. Penerapan prinsip void

d. Disorientasi, pada Fasilitas Permainan Tradisional Melayu Riau terkelompok atas satu bangunan utama yang dikaitkan dengan fungsi tempat permainan tradisional anakanak, wahana permainannya tetap berada pada bagian yang memiliki ukuran paling luas, sehingga, anak-anak dapat dengan mudah untuk bergerak atau beraktivitas (Lihat gambar 15).

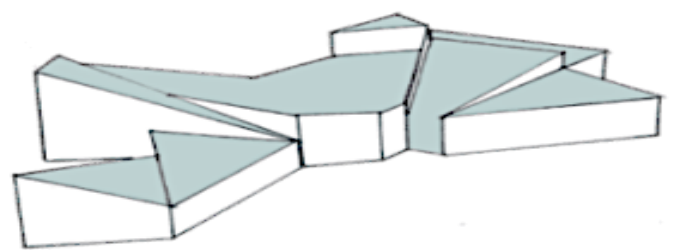

Gambar 12. Penerapan prinsip disorientasi

\section{Tampilan fisik bangunan}

Gaya bangunan

Gaya bangunan disesuaikan dengan fungsi perancangan sebagai tempat/wadah permainan tradisional anak-anak yang mencoba mengadaptasi prinsip desain Daniel Libeskind (Lihat gambar 16). 


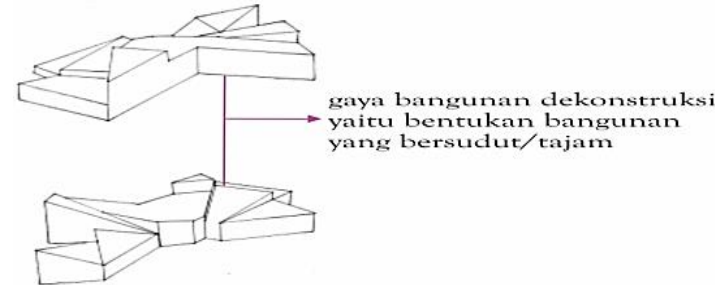

Gambar 13. Gaya bangunan

Gubahan massa

Gubahan massa, terdapat satu gedung utama yang di dalamnya terdapat beberapa jenis permainan indoor dan dilengkapi fasilitas penunjang lainnya. Sesuai dengan prinsip Daniel Libeskind, rancangan bangunan cenderung bersudut (Lihat gambar 17).

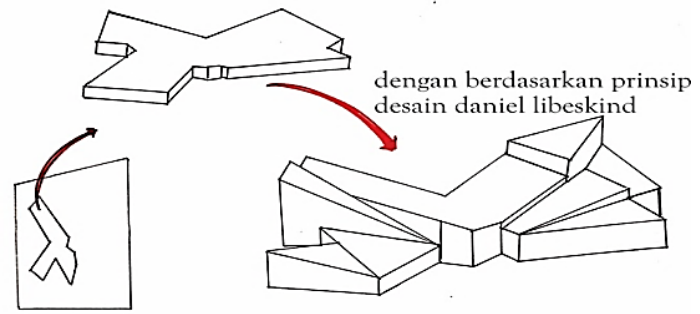

Gambar 14. Gubahan massa

Fasad

Fasad bangunan dilapisi kaca dan dinding kaca, sehingga dapat memasukkan cahaya dari luar ke dalam bangunan dengan lebih mudah (Lihat gambar 18).

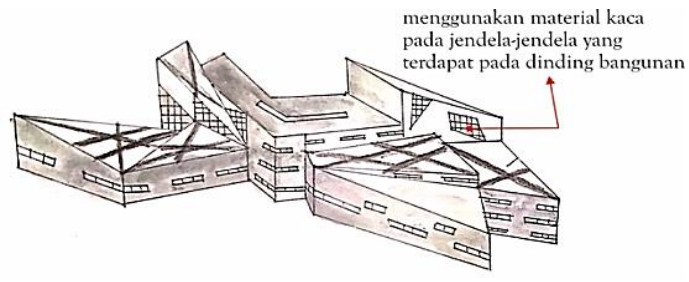

Gambar 15. Penerapan fasad

Bangunan utama yang merupakan fasilitas tempat anak-anak bermain, sambil mengenal permainan tradisional, tempat bersantai menikmati jajanan dan makanan, ruang baca, serta interior ruang pengelola (Lihat gambar 19).
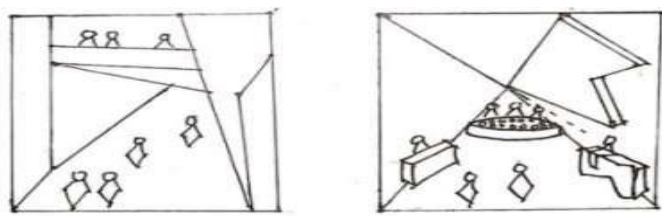

Gambar 16. Interior bangunan utama

\section{Warna}

Pemilihan warna dominan dalam nuansa putih, hitam dan abu-abu. Warna putih lebih banyak digunakan pada elemen interior dinding dan plafond, sedangkan warna hitam digunakan pada lantai, dan pemakain warna abu-abu cenderung digunakan pada eksterior bangunan (Lihat gambar 20).

warna abu-abu ǔntuk

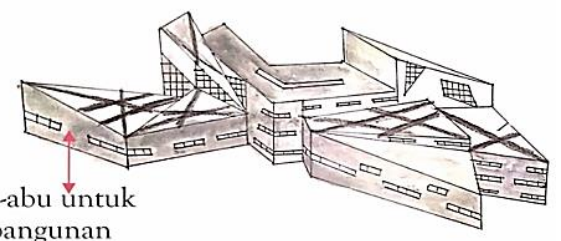

eksterior bangunan

Gambar 20. Warna bangunan

Material

Perancangan fasilitas permainan tradisional Melayu Riau menerapkan dominan material kaca dan baja (Lihat gambar 21).

menggunakan material baja pada bagian atap bangunan

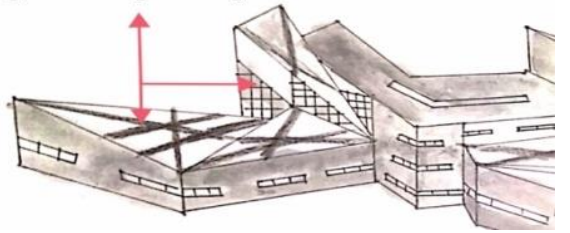

Gambar 17. Material bangunan

\section{Vegetasi}

Konsep pemilihan jenis vegetasi didasarkan atas pertimbangan desain yang tidak membahayakan untuk pengunjung seperti tidak berduri, tidak berujung runcing, tidak bergetah, tidak beracun serta tidak mengundang datangnya serangga atau lebah. Gambar 22 menunjukkan letak area bermain indoor dan outdoor, serta letak vegetasi berada di sekitar bangunan dan di area bermain outdoor.

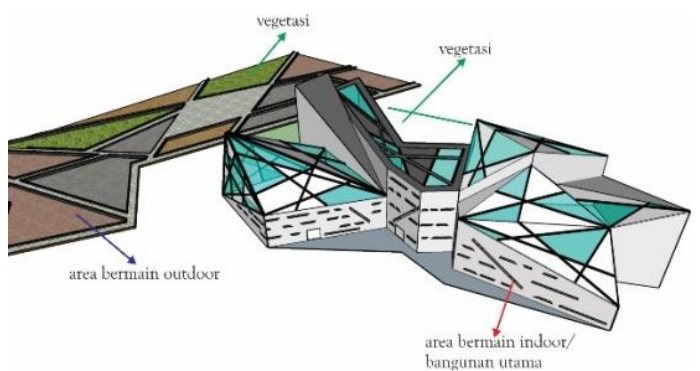

Gambar 18. Rancangan fasilitas 


\section{Kesimpulan}

Kesimpulan yang didapat dalam perancangan ini ialah fungsi yang diterapkan pada rancangan fasilitas permainan tradisional Melayu Riau sesuai sebagai tempat bermain sekaligus memperkenalkan pelbagai macam permainan tradisional Melayu Riau. Pemilihan lokasi dengan jarak tempuh singkat dan berdekatan dengan pusat kota, telah memperkuat penerapan konsep desain gerak dalam bermain statak dengan mengadaptasi prinsip desain Daniel Libeskind melaui penerapan 4 prinsip desain, yaitu: (a) metafora; (b) fragmentation; (c) void, dan (d) disorientation. Pengaplikasian konsep dan pendekatan arsitektur yang dipilih kerancangan bangunan bersudut telah menghasilkan suatu bentukan yang berbeda dengan desain bangunan di sekitarnya.

\section{Referensi}

Andriani, Tuti. 2012. 'Permainan Tradisinal Dalam Membenruk Karakter Anak Usia Dini'. Jurnal Sosial Budaya 9 (1): 121-36. https://media.neliti.com/media/publications/4 0427-ID-permainan-tradisional-dalammembentuk-karakter-anak-usia-dini.pdf.

Angela. 2013. 'Pengaruh Game Online Terhadap Motivasi Belajar Siswa SDN 015 Kelurahan Sidomulyo Kecamatan Samarinda Ilir'. EJournal Ilmu Komunikasi 1 (2). https://ejournal.ilkom.fisipunmul.ac.id/site/?p=853\#.

Bitter, Jan. 2011. Daniel Libeskind: Jewish Museum Berlin: Museum Building Guides. Barcelona: Publisher:

Christina, Safira Caroline, and Filipus Priyo Suprobo. 2017. 'Perancangan Interior Fasilitas Dolanan Edutainment Untuk Anak Usia 4-12 Tahun Di Surabaya'. Intra 5 (2): 871-89. http://publication.petra.ac.id/index.php/desai n-interior/article/viewFile/5927/5414.

Dahliani. 2015. 'Local Wisdom in Built Environment in Globalization Era'. International Journal of Education and Research 3 (6): 157-66. https://www.ijern.com/journal/2015/June2015/13.pdf.

Fatkhiyah, Lulu. 2015. 'Terdapat Banyak Manfaat Dari Permainan Tradisional Untuk
Perkembangan Anak'. Kompasiana Beyond Blogging. 2015. https://www.kompasiana.com/fatchyblablabl a/5548578b547b618a16252543/terdapatbanyak-manfaat-dari-permainan-tradisionaluntuk-perkembangan-anak.

Hasanah, Uswatun. 2016. 'Pengembangan Kemampuan Fisik Motorik Melalui Permainan Tradisional Bagi Anak Usia Dini'. Jurnal Pendidikan Anak 5 (1): 717-33. https://journal.uny.ac.id/index.php/jpa/article/ viewFile/12368/8937.

Hermanto, Meliana. 2013. 'Studi Gaya Desain Interior Museum Karya Daniel Libeskind'. Intra 1 (1). http://publication.petra.ac.id/index.php/desai n-interior/article/view/1565.

Hidayah, Nur. 2016. 'Aspek Edukasi Taman Pintar Yogyakarta'. Jurnal Kebijakan $\begin{array}{lll}\text { Pendidikan } & 5 & \text { (2): } 189-200 .\end{array}$ http://journal.student.uny.ac.id/ojs/index.php/ sakp/article/viewFile/5200/4875.

Lake, Reginaldo Christophori. 2017. 'Metode Pendekatan Desain Menurut Henry Bergson Dan Gilbert Ryle Terhadap Arsitektur Dekonstruksi'. In Penerapan Ipteks Dalam Mendukung Pembangunan Yang Berkelanjutan, 51-56. Kupang: Prodi Arsitektur Fakultas Teknik Universitas Katolik Widya Mandira.

Mantiri, Hyginus J., and Indradjaja Makainas. 2011. 'Eksplorasi Terhadap Arsitektur Dekonstruksi'. Media Matrasain 8 (2). https://ejournal.unsrat.ac.id/index.php/jmm/ar ticle/view/327/0.

Neufert, Ernest. 2002. Data Arsitek. 33rd ed. Jakarta: Erlangga.

Nurhaidah, M. Insya Musa. 2015. 'Dampak Pengaruh Globalisasi Bagi Kehidupan Bangsa Indonesia'. Pesona Dasar : Jurnal Pendidikan Dasar Dan Humaniora 3 (3): 1-14.

Pemerintah Provinsi Riau. 2015. Peraturan Daerah Provinsi Riau Nomor 9 Tahun 2015 Tentang Pelestarian Kebudayaan Melayu Riau. Indonesia.

Pertiwi, Sofi Wildan, and Istijabatul Aliyah. 2017. 'Konservasi Permainan Tradisional Sebagai Daya Tarik Wisata Kampung, Studi Kasus: 
Kampung Dolanan Sidowayah, Kabupaten Klaten'. Cakra Wisata 18 (2): 35-47.

Rini, Ayu. 2011. Menanggulangi Kecanduan Game Online Pada Anak. Jakarta: Pustaka Mina.

Rohmah, Naili. 2016. 'Bermain Dan Pemanfaatannya Dalam Perkembangan Anak Usia Dini'. Tarbawi: Jurnal Pendidikan Islam 13 (2): 27-35.

Santoso, Rizqi Iman. 2015. 'Nasib Permainan Tradisional: Punahkah Permainan Tradisional Kita?' Kompasiana Beyond Blogging. 2015. https://www.kompasiana.com/rinsogaul99/54 f91315a33311f9028b4647/nasib-permainantradisional.

Saputra, Geri Barnas, Muksin Muksin, and Merry Muspita. 2018. 'Pengembangan Agrowisata Di Kecamatan Ledokombo, Kabupaten
Jember'. Jurnal Ekonomi Pertanian Dan Agribisnis 2 (4): $325-31$. https://doi.org/10.21776/ub.jepa.2018.002.04. 7.

Senasaputro, Bonifacio Bayu, and Wiendu Nuryanti. 2008. 'Daniel Libeskind: Kajian Teori, Metoda dan Aplikasi Perancangan'. Universitas Gadjah Mada. http://etd.repository.ugm.ac.id/home/detail_p encarian/39966.

Sudradjat, Iwan. 2020. 'Teori Dalam Penelitian Arsitektur'. ARTEKS: Jurnal Teknik Arsitektur 5 (1): https://doi.org/10.30822/arteks.v5i1.378. 